\title{
CONCEPT OF KNOWLEDGE MANAGEMENT IN MODERN ENTERPRISES
}

doi: $\quad 10.2478 /$ czoto-2019-0125

Date of submission of the article to the Editor: 04/12/2018

Date of acceptance of the article by the Editor: 28/01/2019

\author{
Sylwia Stachera-Włodarczyk ${ }^{1}$ - orcid id: 0000-0001-7414-9113 \\ ${ }^{1}$ Czestochowa University of Technology, Poland, sylwia.stachera-wlodarczyk@wz.pcz.pl
}

\begin{abstract}
The article presents a multi-aspect approach to the knowledge management system. Knowledge management focuses on the problem of creating and disposing of intellectual competence resources and practical skills, which are intangible assets of an enterprise. They concern different fields of science and empirical applications, and they are used to achieve a significant competitive advantage. In addition, knowledge management is focused on learning processes and improving the skills of the organization's employees, systematizing and using knowledge in business practice. Therefore, effective use of knowledge management principles can contribute to increasing the effectiveness of the company's operations and improving its competitive position.

The aim of this article is to present the concept of knowledge management through a critical analysis of domestic and foreign literature on issues related to knowledge processes, approaches to knowledge management and practices. The featured problem will be presented not only from the theoretical but also the practical side. Based on surveys conducted using the survey method, the most important benefits and barriers associated with introducing the concept of knowledge management or its elements in the enterprise will be identified.
\end{abstract}

Keywords: knowledge, knowledge management, benefits from knowledge management, barriers in knowledge management

\section{INTRODUCTION}

Nowadays, enterprises seek a variety of management methods to achieve a competitive advantage on the market. Using just material resources often turns out to be insufficient. Therefore, they began to pay special attention to intangible assets. Currently, such a resource is knowledge, which is a special area of activity of each company, and its skillful use is the source of its success.

Knowledge management, which is used by more and more enterprises, is a proven concept in practice. An important task of knowledge management is shaping the progress in all areas of activity of a given sub-milieu. Knowledge management focuses on the problem of creating and disposing of intellectual resources and practical skills, which are intangible assets of an enterprise. It is a process of 
identifying, acquiring and using knowledge, the primary goal of which is to improve the competitive position of an enterprise.

This article aims to familiarize and broaden the issues in the field of knowledge management in the company's operations. It presents general issues related to knowledge, knowledge management and the benefits and threats resulting from the implementation of the concept of knowledge-making in the enterprise were considered.

\section{METHODOLOGY OF RESEARCH}

The article has been divided into two parts, i.e. theoretical and practical. The method of critical analysis of literature, both domestic and foreign, was used to develop the theoretical part of the article. The empirical part of the work was prepared based on pilot surveys. The survey questionnaire was standardized, included closed questions and was directed to a group of 50 medium-sized enterprises operating in the Silesian Voivodship (mainly the Czestochowa county).

\section{RESULTS AND DISCUSSION}

Currently, many enterprises are aware of the importance of not only skillful use of knowledge but also adequate management of said knowledge in the enterprise. In this area lies the creative potential of each enterprise - conditioning the acquisition of a competitive advantage.

\subsection{THE ESSENCE AND THE IMPORTANCE OF KNOWLEDGE}

The term knowledge is variously interpreted in the literature on the subject. In most definitions, it is identified with data and information. It is assumed that knowledge is information placed in the right context that enables the enterprise and its employees to act effectively and efficiently (Brdulak, 2005). It is therefore a productive use of information (Armstrong, 2001). Knowledge affects the ability to compete and contributes to achieving a sustainable competitive advantage because it is a source of innovation (Kowalczyk and Nogalski, 2007). In addition, it has a significant impact on the actions taken, decisions and organizational behavior (Rowley, 2000). Each knowledge has some characteristic features for it, the most common ones are presented in table 1.

Table 1

Basic attributes of knowledge

\begin{tabular}{|c|l|}
\hline ATTRIBUTE & \multicolumn{1}{|c|}{ CHARACTERISTIC } \\
\hline dominance & $\begin{array}{l}\text { The future of the organization, its competitive advantage in } \\
\text { the coming period depends mainly on the effective use of } \\
\text { the resource, which is knowledge, Knowledge plays } \\
\text { a superior role in relation to all other resources. }\end{array}$ \\
\hline \multirow{5}{*}{ Inexhaustibleness } & $\begin{array}{l}\text { In contrast to other factors of production, } \\
\text { the value of knowledge and information is not diminishing, } \\
\text { on the contrary - the more knowledge is used and more } \\
\text { often, its value increases. Knowledge is a resource that does } \\
\text { not wear out. }\end{array}$ \\
\hline simultaneity & $\begin{array}{l}\text { In contrast to the classic factors of production, the same } \\
\text { knowledge can be used simultaneously by many } \\
\text { organizations and / or people and in many places. }\end{array}$ \\
\hline
\end{tabular}




\begin{tabular}{|c|l|}
\hline nonlinearity & $\begin{array}{l}\text { This feature means that the amount of knowledge does not } \\
\text { indicate its usefulness. Non-linearity also means that the } \\
\text { same dose of knowledge used in one organization can have } \\
\text { completely different consequences, as in the situation of } \\
\text { using it in another organization. However, when using } \\
\text { knowledge, benefits of scale may or may not occur. }\end{array}$ \\
\hline immateriality & $\begin{array}{l}\text { This feature means that knowledge is elusive and cannot be } \\
\text { presented in the form of traditional accounting measures or } \\
\text { others used by organizations. It cannot be easily captured in } \\
\text { a specific framework. }\end{array}$ \\
\hline
\end{tabular}

Source: (Strojny, 2002; Jarugowa and Fijałkowska, 2002).

Some authors, considering knowledge as a company resource, also indicate the following features (Mikuła et al., 2002), namely:

- it can be created by various methods;

- is relative and ambiguous, so it can be interpreted differently by individual people;

- is dynamic, i.e. capturing only a small part of it can lead to its large increase, as well as has the ability to grow during its use;

- it quickly becomes obsolete;

- reduces uncertainty in the case of risky ventures;

- by codification undergoes structuring in technologies, procedures, organizational documentation, people's competences and databases;

- materializes, or externalizes, in products and services, which makes it so

that you can imitate it.

Knowledge is therefore a flexible and dynamic non-material substance that arises from the processing of mental information that people have at their disposal or acquires them from their surroundings. Because the thought process, creating knowledge, is directed by intuition, knowledge is relative. In practice, this means that a specific subject can present a completely different quality for people who study it with different methods (Mikuła et al., 2002).

Multidimensionality of knowledge causes that we can divide it into four basic categories (Kowalczyk, Nogalski, 2007):

- to know what - resources referring to facts and taking form, data that can be easily stored and transmitted.

- know why - it is knowledge of causal relationships, knowledge of the laws and principles of action of nature, society, technology, etc.

- to know how - this knowledge refers to skills and experience, it is the basis for practical action and manifestation in the form of qualifications and skills.

- to know who - it is a resource that is the domain of an individual or team and applies to those who have the above-mentioned types of knowledge.

Knowledge is not only one of the company's main resources, but also constitutes the basis for defining strategic elements of the business management system (Kłak, 2010). The important strategic nature of knowledge results firstly from its more difficult imitation and substitution compared to material resources, and secondly from its greater flexibility (Trajer et.al, 2004). The scope and method of defining knowledge and the adoption of certain types of it in the organization determines the solutions that are adopted as part of knowledge management. 


\subsection{SPECIFICATION OF KNOWLEDGE MANAGEMENT}

Knowledge management is a field of management that emerged in the first half of the nineties of the twentieth century as the result of comprehensive discussions about the potential benefits of knowledge sharing. Today's enterprises realize that proper knowledge management can bring them many benefits.

Knowledge management consists in skillful use of intellectual capital and obtaining a synergistic effect, i.e. obtaining better results than would result from the direct use of individual resource elements that the organization has at its disposal (Kisielnicki, 2007; Scheepers et.al., 2004). Knowledge management should aim to develop methods and techniques that enable effective processes of creating, collecting and using knowledge. It involves the creation of a project to use it, with the objectives of this project including: building a corporate knowledge base, increasing access to knowledge, and introducing a culture of knowledge (Skrzypek, 2002; Sharp, 2003; Smoliar, 2003).

The contemporary concept of "knowledge management" has already received many definitions depicting its essence, which is presented in Table 2.

Table 2.

The essence of knowledge management

\begin{tabular}{|c|c|}
\hline AUTHOR & DEFINITION OF KNOWLEDGE MANAGEMENT \\
\hline Klasson & $\begin{array}{l}\text { the ability to create and retain as much value as possible } \\
\text { for the organization's basic business activities }\end{array}$ \\
\hline $\begin{array}{l}\text { Bennet } \\
\text { and Gabriel }\end{array}$ & $\begin{array}{l}\text { ability to manage information, knowledge and experience, i.e. their } \\
\text { creation, collection, storage and use to ensure future development } \\
\text { based on resources }\end{array}$ \\
\hline Skryme & $\begin{array}{l}\text { systematic activities related to knowledge and processes of creating, } \\
\text { collecting, organizing, carried out in pursuit of organizational goals }\end{array}$ \\
\hline Stewart & $\begin{array}{l}\text { having knowledge about what we know, acquiring and organizing it, } \\
\text { and using it in a way that brings certain benefits }\end{array}$ \\
\hline Perechuda & $\begin{array}{l}\text { is a process of continuous implementation of management functions, } \\
\text { focused on knowledge-based resources (internal and external, existing } \\
\text { and non-existent, known and hidden) and tasks and instruments of } \\
\text { organizing and communicating }\end{array}$ \\
\hline $\begin{array}{l}\text { Bukowitz and } \\
\text { Williams }\end{array}$ & $\begin{array}{l}\text { is a process by which an organization generates wealth based on its } \\
\text { intellectual or knowledge-based organizational assets }\end{array}$ \\
\hline Sarvary & $\begin{array}{l}\text { is a business process thanks to which companies create and apply their } \\
\text { institutional or collective knowledge in practice }\end{array}$ \\
\hline Davenport & $\begin{array}{l}\text { it is a composition of targeted experience, useful information, } \\
\text { professional view and value. This composition creates the basis for the } \\
\text { assessment and assimilation of information and new experiences. } \\
\text { Knowledge is shaped in human minds in the form of customs, norms } \\
\text { and procedures }\end{array}$ \\
\hline Kisielnicki & $\begin{array}{l}\text { It is a process in which we can use the resources of the company's } \\
\text { knowledge, search and absorb external knowledge resources as well as } \\
\text { create favorable conditions in which all participants of the decision- } \\
\text { making process would feel obliged to share their knowledge and create } \\
\text { it }\end{array}$ \\
\hline
\end{tabular}

Source: (Karaś E., Piasecka-Głuszak A, 2013; Skryme, 1999; Bukowitz and Williams, 2000; Perechuda, 2005; Davenport, 2007, Kisielnicki, 2004) 
The essence of knowledge management indicates the necessity of continuous learning, it can be considered at least from four points of view (Mikuła, 2007; Plessis, 2007; Skrzypek, 2012):

- in functional terms, as a process involving the implementation of management functions focused on the knowledge resources and processes in which they participate, and the conditions for their implementation, in a manner enabling efficient achievement of the organization's goals,

- in procedural terms, as standardization proceedings aimed at creating an appropriate environment that will enable the efficient implementation of knowledge management tasks.

- in instrumental terms, as selection and use of instruments contributing to the course of major processes involving knowledge at all levels and areas of the organization.

- in institutional terms, as a system of positions and teams of employees performing functions in the field of knowledge management.

The basic goal of knowledge management is the appropriate shaping of knowledge resources in the organization and ensuring its smooth flow in individual functional areas of the enterprise (Karaś E., Piasecka-Głuszak A, 2013). Various interpretations of knowledge management objectives are presented in Table 3.

Table 3

Selected approaches to knowledge management goals

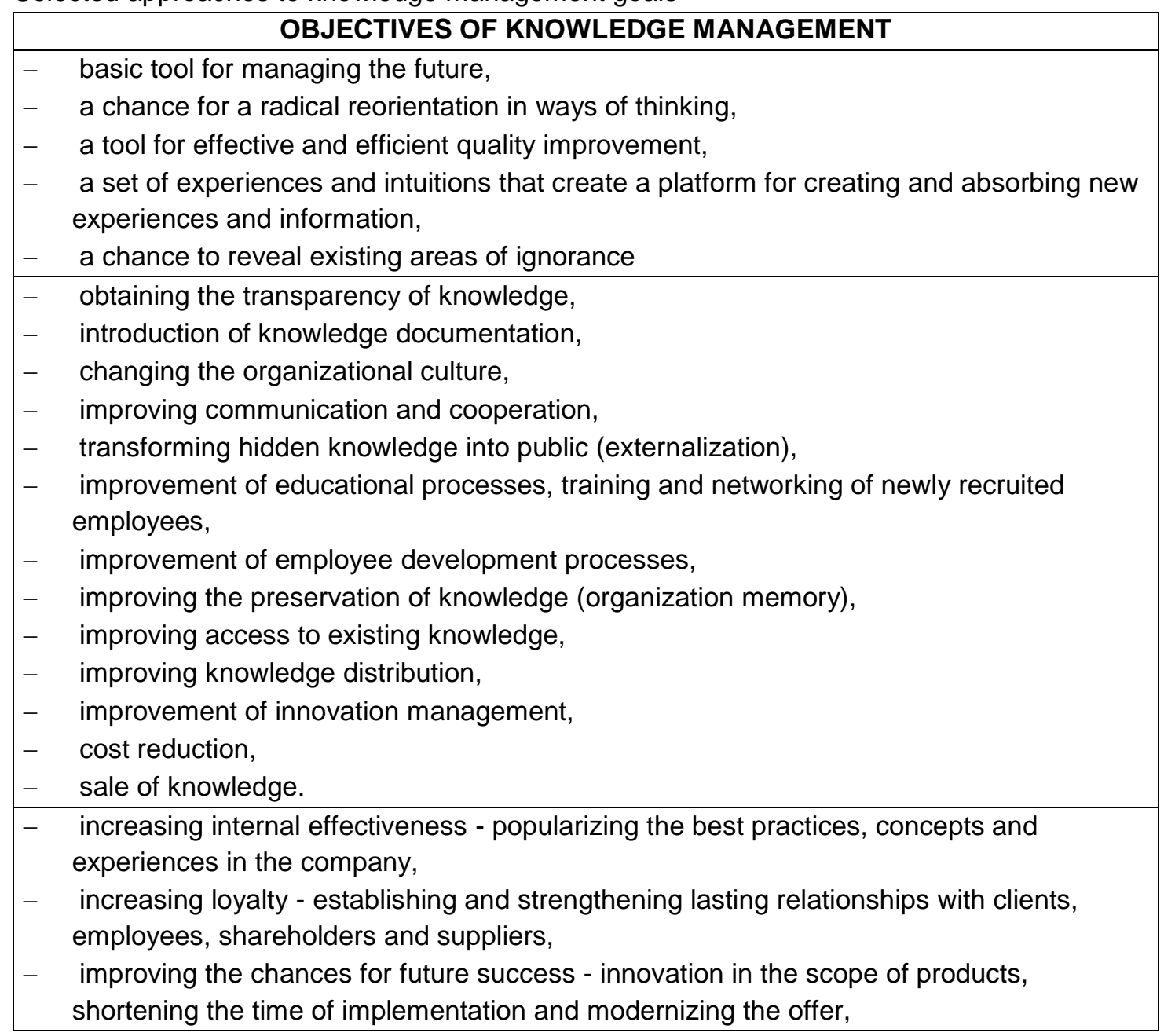


$-\quad$ creating a culture based on the paradigm of values - shaping attitudes, skills and
experiences conducive to broadening basic competences and generating value,
increasing decision effectiveness - making the right decisions thanks to the right
information provided to the right people at the right time. Source: (Skrzypek 2002; Maier, 2001; Kowalczyk and Nogalski 2007;)

It should be emphasized that the full achievement of the indicated knowledge management goals is possible due to the proper integration of activities in its scope with the activities carried out under other organizational management subsystems.

\subsection{IMPORTANCE OF KNOWLEDGE MANAGEMENT - RESULTS OF OWN RESEARCH}

Knowledge management can bring measurable benefits to the organization, which mainly boils down to the creation of an effective management system. They can be considered at three levels, namely at the level of (Błaszczuk, 2004):

- companies, the benefits achieved come down to two dimensions: the organizational one (which includes the relationship between the enterprise and the employee) and the organizational one (including the relationship with the environment),

- employees, benefits are here to create an organizational culture that allows the free flow of knowledge leading to the continuous development of employees,

- market, these benefits relate primarily to the exchange of knowledge and experience with direct market partners.

On the other hand, it should be remembered that when introducing the concept of knowledge management in enterprises, very often problems arise that come from the misunderstanding of its essence, lack of knowledge of basic principles or incorrect flow of information. From the point of view of the company, this is a quite significant problem.

The research carried out was aimed at diagnosing the approach of Polish enterprises to knowledge management processes. The subject of the study covered mainly the knowledge management process, in particular the benefits resulting from its implementation and barriers related to its implementation. Pilot studies were conducted to obtain information in this field. The research was carried out using the questionnaire method. The questions were closed and the questionnaire was standardized, which means that all the participants were asked the same questions and in the same order. The research was anonymous. The research covered a group of 50 medium-sized enterprises operating in the Śląskie Voivodeship (mainly the Częstochowa poviat).

First of all, the focus was on the benefits that an enterprise can implement the concept of knowledge management. Among others respondents were asked, to what extent skillful knowledge management influences the course of the communication process in an enterprise, whether it contributes to the improvement of the efficiency of the company's operation and what is its relation to the improvement of employees' competences. The respondents were asked to make an assessment and determine the validity of the potential benefits indicated in the survey that may arise in enterprises implementing the concepts of knowledge management. Respondents made the assessment based on a scale from 1 to 5 , where 1 meant the least important benefit and the 5th most important. 
Table 4

Identification of the most important benefits in the knowledge management process in the opinion of respondents

\begin{tabular}{|l|c|}
\hline \multicolumn{1}{|c|}{ TYPE } & FREQUENTIAL EVALUATION \\
\hline $\begin{array}{l}\text { improving communication and speeding up the } \\
\text { decision-making process }\end{array}$ & 5 \\
\hline increase in enterprise innovation & 2 \\
\hline accelerating the creation of a rich product offer & 3 \\
\hline shortening the time of solving key problems & 3 \\
\hline improvement of the company's efficiency in the market, & 4 \\
\hline $\begin{array}{l}\text { broadening the competence and knowledge of } \\
\text { employees }\end{array}$ & $\mathbf{5}$ \\
\hline
\end{tabular}

Source: own elaboration

As can be seen from the data presented in Table 4, the most important benefits which, according to the respondents 'opinion, bring enterprises the implementation of the knowledge management process include improving communication and speeding up the decision-making process and broadening the employees' competences and knowledge. Respondents saw the potential in people who want to develop, integrate and interact with others. The speed of decision making and the flow of information were also important. The least important, however, was the increase in enterprise innovation.

Analysis of respondents' answers concerning barriers in knowledge management processes revealed several groups of factors negatively affecting this process. Respondents were supposed to choose - from the proposals indicated in the survey barriers that in their opinion affect the process of knowledge management in their enterprises. Then, similarly to the case of benefits analysis, they were to assess them (using 1-5 scale). The results obtained from the tests have been included in table 5 .

Table 5

Identification of the most important barriers in the knowledge management process in the opinion of respondents

\begin{tabular}{|l|c|}
\hline \multicolumn{1}{|c|}{ TYPE } & $\begin{array}{c}\text { FREQUENTIAL } \\
\text { EVALUATION }\end{array}$ \\
\hline lack of financial resources for acquiring and developing knowledge, & 4 \\
\hline inability to transfer knowledge, poor communication & $\mathbf{5}$ \\
\hline $\begin{array}{l}\text { lack of awareness of the importance of knowledge in management } \\
\text { processes, }\end{array}$ & 3 \\
\hline no time to analyze knowledge processes, & 3 \\
\hline $\begin{array}{l}\text { lack or imperfection of technical means for storing and transforming } \\
\text { knowledge and information. }\end{array}$ & 2 \\
\hline resistance to sharing knowledge & $\mathbf{5}$ \\
\hline
\end{tabular}

Source: Own elaboration

According to the respondents, the most important barriers in knowledge management processes are: inability to transfer knowledge and resistance to sharing knowledge. Very often, employees do not share knowledge because they do not want to do it. They keep it for themselves for fear of losing their position in the company. This is partly due to the poor management style in the company, manifested by the lack of team-working skills and the inability to meet human potential. An important barrier, in 
the opinion of respondents, is also the lack of necessary financial resources for acquiring and developing knowledge.

\section{CONCLUSION}

The multifaceted nature of knowledge management means that it requires the separation of basic areas of knowledge management. Currently, knowledge is the dominant element of the resources of each enterprise, and knowledge management is a concept that currently has a strong impact on the development of enterprises and determines its further functioning in the future.

Effective knowledge management in enterprises should bring them many benefits. On the one hand, it enables the improvement of the functioning of all processes taking place in the enterprise as part of the management process, and on the other hand affects their quality and efficiency. Thanks to the introduction of improvements resulting from the knowledge management process, the company becomes a reliable market partner and is positively perceived on the market. It is also important to skillfully use the potential of employees, which has a positive impact on the competitive position of the company. It should be remembered, however, that enterprises implementing knowledge management concepts are forced to incur high costs related to, among other things, creating appropriate IT infrastructure or training their employees so that they can use knowledge resources.

\section{Reference:}

Bałaszczuk, A., 2004. Korzyści z zarządzania wiedzą. Oficyna Wydawnicza Szkoły Głównej Handlowej, Warszawa, 40-41.

Brdulak, J.J., 2005. Zarządzanie wiedzą a proces innowacji produktu. Budowanie przewagi konkurencyjnej firmy, Szkoła Główna Handlowa, Warszawa, 14.

Bukovitz, W.R., Williams, R.L., The Knowledge Management Fieldbook. Financial Time, Prentice Hall, London, 2

Davenport, T. H., 2007. Zarządzanie pracownikami wiedzy. Wolters Kluwer Polska, Difin, Warszawa.

Jarugowa, A., Fijałkowska, J, 2002. Rachunkowość i zarządzanie kapitałem intelektualnym. Koncepcje ii praktyka, Ośrodek Doradztwa i Doskonalenia Kadr Sp. z o.o., Gdańsk, 17-18.

Karaś, E., Piasecka-Głuszak, A., 2013. Zarządzanie wiedzą - dlaczego tak ważne. [w:] „Nauki o Zarządzaniu”, Uniwersytet Ekonomiczny we Wrocławiu, 4(17).

Kisielnicki, J., 2004. Zarządzanie wiedzą we współczesnych organizacjach. [w:] Zarządzanie wiedzą w systemach informacyjnych, Wydawnictwo AE Wrocław, Wrocław.

Kisielnicki, J., 2007. Kapitał intelektualny w procesie zarządzania wiedzą: relacje $i$ czynniki. Problemy Zarządzania, 4(18), 26-42.

Kłak, M., 2010. Zarządzanie wiedzą we współczesnym przedsiębiorstwie. Wydawnictwo Wyższej Szkoły Ekonomii i Prawa, Kieleckie Towarzystwo Edukacji Ekonomicznej, Kielce, 51, 55.

Kowalczyk, A., Nogalski, B., 2007. Zarządzanie wiedzą. Koncepcja i narzędzia. Difin, Warszawa.

Maier, R., 2002. Knowledge Management Systems. Information and Communication Technologies for Knowledge Management, Springer-Verlag Berlin, Heidelberg 
Mikuła, B., 2007. Od strategicznego do operacyjnego zarządzania wiedzą. [w:] Zarządzanie wiedzą. Wybrane problemy, Leja K., Szuwarzyński A. (red.), Wyd. Katedra Zarządzania Wiedzą i Informacją, Politechnika Gdańska, Gdańsk.

Mikuła, B., Pietruszka-Ortyl, A., Potocki, A., 2002. Zarządzanie przedsiębiorstwem XXI wieku. Wybrane koncepcje i metody, Difin, Warszawa, 72-73.

Perechuda, K., 2005. Jakościowe kreowania wiedzy - podejście japońskie. [w:] Zarządzanie wiedzą w przedsiębiorstwie, praca zbiorowa pod red. K. Perechudy, Wydawnictwo Naukowe PWN, Warszawa.

Plessis, M., 2007. The role of knowledge management in innovation. Journal of Knowledge Management, 11 (4).

Rowley, J., 2000. From learning organization to knowledge entrepreneur. „Journal of Knowledge Management", 4(1), McGraw-Hill/Irwin, New York.

Scheepers, R., Venkitachalam, K., Gibbs, M.R., 2004. Knowledge strategy in organizations: Refining the model of Hansen, Nohria and Tierney, Journal of Strategic Information Systems, 13.

Sharp, D. 2003. Knowledge management today: challenges and oportunites. Information Processing and Management, 20(2).

Skrzypek, E., 2012. Jakościowy wymiar zarzadzania wiedzą - teoria i praktyka. „Zarzadzanie i finanse”.

Skrzypek, E., 2002. Jakość i efektywność. Wydawnictwo UMCS, Lublin.

Skyrme, D. J., 1999. Knowledge Networking. Creating the Collaborative Enterprise, Butterworth Heinemann, Oxford.

Smoliar, S.W., 2003. Interaction management: The next (and necessary) step beyond knowledge management. Business Process Management Journal, 9(3).

Trajer, J., Paszek, A., Iwan, S., 2012. Zarządzanie wiedzą. PWE, Zarządzanie wiedzą w przedsiębiorstwach, praca zbiorowa pod red. W.M. Grudzewskiego i I. Hejduk, Difin, Warszawa 2004. 